\title{
In vitro risk assessment of Padina pavonica (Linnaeus) (Brown algae)
}

\section{Adem GÜNER@}

Cite this article as:

Güner, A. (2021). In vitro risk assessment of Padina pavonica (Linnaeus) (Brown algae). Food and Health, 7(1), 31-38.

https://doi.org/10.3153/FH21004

Giresun University, Faculty of Science and Art, Department of Biology, Güre, Giresun, Turkey

ORCID IDs of the authors: A.G. 0000-0003-3295-3538

Submitted: 12.05 .2020

Revision requested: 01.09 .2020

Last revision received: 08.09 .2020

Accepted: 04.10.2020

Published online: 09.11.2020

Correspondence:

Adem GÜNER

E-mail: ademeguner@gmail.com

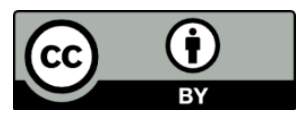

(C) 2021 The Author(s)

Available online at

http://jfhs.scientificwebjournals.com

\begin{abstract}
Padina pavonica (Linnaeus) Thivy 1960 is a brown algae that is antioxidant, antimicrobial, and anticancer effects and is generally used in soup, salad, and other dishes. However, no studies have been reported on safe consumption in humans to date. For this purpose, this study was conducted to determine the cytotoxic and genotoxic effects of $P$. pavonica on lymphocytes cultured from human blood. The water extract of $P$. pavonica was added into culture tubes at various concentrations $(0.5-1000 \mu \mathrm{g} / \mathrm{mL})$. Cytotoxic effects were determined by MTT assay. Antioxidant/oxidant status was evaluated by total antioxidant capacity (TAC) and total oxidative status (TOS) assays. Genotoxic effects were investigated by sister chromatid exchanges and micronucleus assays. Our results showed that $P$. pavonica had no genotoxic effects, even at higher concentrations. 1000 $\mu \mathrm{g} / \mathrm{mL}$ concentration of $P$. pavonica caused an increase $(\mathrm{P}<0.05)$ TOS levels while significantly reducing cell viability. However, low concentrations (50 and $100 \mu \mathrm{g} / \mathrm{mL}$ ) significantly increased $(\mathrm{P}<0.05)$ TAC levels. In conclusion, $P$. pavonica can be safely consumed with its non-genotoxic and antioxidant properties in a manner dose-dependent.
\end{abstract}

Keywords: Algae, Antioxidant, Genotoxic, Oxidative stress, Padina pavonica 


\section{Introduction}

Algae is a group of photosynthetic organisms that can be found almost anywhere on the earth, consisting of multi or single-cell organisms without root, stem, and leaf differentiation. Algae has superior survival ability despite different environmental stimuli (UV, temperature, $\mathrm{pH}$, heat, etc.) in their environment (Field et al., 1998; Güner et al., 2015). These features are often associated with secondary metabolites in their structure. Numerous studies reported that active metabolites of algae have antioxidant, antimicrobial, anticancer, anticoagulant, wound healing, and anti-inflammatory activities and their significant part is used in many medicines, pharmacy, agricultural, and cosmetics products (Mohamed et al., 2012; Güner et al., 2018; Güner et al., 2019; Güner et al., 2020). Algae have been also consumed as a traditional food ingredient in many countries since ancient times thanks to amino acids, vitamins, protein, terpenoids, fatty acids, minerals, sterols, and phenolic compounds in its structure. For this purpose, open and closed algae cultivation systems have been developed to meet the needs in many countries, especially in China and Japan. In particular, wakame (Undaria sp.), nori (Porphyra sp.), and Kombu (Laminaria sp.) that are derived from different algae family are among the most nutritious algae foods (McHugh, 2003).

Padina pavonica L. is a brown algae from the Dichtyophyceae family, is one of the common macro-algae species worldwide. Its most characteristic feature is that it has a calcareous structure and therefore it is a rich calcium carbonate deposit. Several studies revealed the antioxidant, antifungal, and antimicrobial effects of $P$. pavonica (Khaled et al., 2012; Stanojkovic et al., 2013). At the same time, Padina $\mathrm{sp}$. is widely used in cosmetics, pharmaceutics, and medicine thanks to rich alginic acid and fucoidan ingredients. Padina sp. is an important food supply in coastal countries. It is especially used to add flavor to soups, salads, and fritters. Also, dried Padina flakes can be added are added to enrich the mineral content of many dishes such as omelet, potatoes, and salads (Pereira, 2016).

According to the literature data, over consumption of seaweeds can cause side effects such as digestive discomfort, thyroid problems, and possible exposure to heavy metals (Cherry et al., 2019). However, no information is available on the safe consumption of edible $P$. pavonica. This study was carried out to reveal whether $P$. pavonica causes cytotoxic, oxidative, and genotoxic effects on lymphocytes cultured from human blood.

\section{Materials and Methods}

P. pavonica was collected at a depth of 1-2 $\mathrm{m}$, in a region of high light intensity, from the coastline of Urla, Izmir. The voucher specimen (number: 41331) was deposited in the Toxicology Laboratory of Ege University, Faculty of Science, Department of Biology. The samples were washed three times with tap water to remove salt, epiphytes, and sand attached to the surface, then carefully rinsed with fresh water, and maintained in a refrigerator at $-20^{\circ} \mathrm{C}$.

\section{Extraction}

For water extraction of algae, $100 \mathrm{~g}$ sample was added to 500 $\mathrm{mL}$ distilled and boiling water using a magnetic stirrer for 15 min. Then the extracts were filtered over Whatman No. 1 paper (Güner et al., 2012).

\section{Experimental Design}

We obtained heparinized blood samples from two healthy non-smoker men, with no history of genotoxic agent exposure. Experiments were conducted with volunteer human subjects according to the Helsinki Declaration. Each blood donor was questionnaired to assess the history of exposure and signed consent forms were obtained. Approximately $4 \mathrm{ml}$ of blood was collected by vein puncture from the participants on an empty stomach to minimize the potential effects of nutritional factors. Hematological and biochemical parameters were analyzed for all volunteers and no pathology was detected. Human peripheral blood lymphocyte cultures were established based on the protocol previously described by Güner et al., (2012). $3 \mathrm{~mL}$ of a fresh blood sample collected into an EDTA tube was transferred to a $15 \mathrm{ml}$ conical centrifuge tube containing an equal amount of Histopaque-1077 (Sigma-Aldrich, St Louis, MO) and then lymphocyte cells were obtained according to the manufacturer's product protocol. Subsequently, the lymphocyte suspension $(500 \mu \mathrm{L})$ was added to $7 \mathrm{ml}$ of Chromosome Medium B (Biochrom, Leonorenstr. 2-6.D-12247, Berlin) containing $100 \mathrm{U} / \mathrm{mL}$ penicillin, $100 \mu \mathrm{g} / \mathrm{mL}$ streptomycin, and $0.005 \mu \mathrm{g} / \mathrm{mL}$ of phytohemagglutinin (Biochrom). The compounds for determining biochemical analysis and genotoxic effects were incorporated into the blood cultures following methods as mentioned below. However, mitomycin $\mathrm{C}\left(10^{-7} \mathrm{M}\right)$ was used as the positive control in the cytotoxic and genotoxic assay. Hydrogen peroxide $\left(\mathrm{H}_{2} \mathrm{O}_{2}\right)(25 \mu \mathrm{M})$ and ascorbic acid $(10 \mu \mathrm{M})$ were used as the positive controls in oxidant and antioxidant analysis, respectively. 


\section{Cell Viability}

MTT [3-(4, 5- dimethyl-2-thiazolyl) -2, 5-diphenyl-2H-tetrazolium bromide)] assay was set up according to a slight modification of the previous protocol (Atmaca et al., 2020). The cells were seeded at approximately $1 \times 10^{4}$ cells/well in a final volume of $200 \mu \mathrm{l}$ in 96-well flat-bottom microtiter plates. After overnight incubation, cells were treated with the various concentrations $(0.5,5,25,50,100,250,500$, and $1000 \mu \mathrm{g} / \mathrm{mL}$ ) of $P$. pavonica and incubated for $24 \mathrm{~h}$ at $37^{\circ} \mathrm{C}$ in a $5 \% \mathrm{CO}_{2}$ incubator. At the end of incubation, $20 \mu \mathrm{L}$ of MTT solution was added to each well and the cells were incubated for an additional $4 \mathrm{~h}$. Then, the medium was removed and the formed formazan crystals were dissolved by DMSO. The amount of formazan proportional to the number of viable cells was measured by using spectrophotometer recording changes in absorbance at $570 \mathrm{~nm}$ (Tecan Infinite 200 PRO, Switzerland).

\section{Total Antioxidant Capacity (TAC) and Total Oxidative Stress (TOS)}

Measurements of TAC and TOS levels was carried out using commercial kits according to the manufacturer's instructions (Rel Assay Diagnostics, Gaziantep, Turkey). For these experiments, another group of cells was treated with $P$. pavonica at different concentrations $(0.5-1000 \mu \mathrm{g} / \mathrm{mL})$ and incubated at $37{ }^{\circ} \mathrm{C}$ in humidified $5 \% \mathrm{CO}_{2}$ for 2 hours.

Potential antioxidants in the culture medium led to the reduction of the ABTS radical (2,2'-azino-bis 3-ethyl benzothiazoline-6-sulfuric acid) in TAC analysis. Briefly, $500 \mu \mathrm{L}$ of Reagent 1 solution was added to a quartz cuvette containing $30 \mu \mathrm{L}$ of plasma sample and after 30 minutes, the initial absorbance was recorded at $660 \mathrm{~nm}$. Then, $75 \mu \mathrm{L}$ of Reagent 2 solution was added to the same cuvette and the absorbance was measured at $660 \mathrm{~nm}$ after $5 \mathrm{~min}$ incubation. The test was calibrated with Trolox and the obtained results were expressed in $\mathrm{mM}$ Trolox equivalent per liter ( $\mathrm{mmol}$ Trolox equiv./L).

The principle of TOS assay was based on the conversion of the ferrous ion chelator complex to ferric ion by oxidants present in the medium. The TOS level was determined by mixing $500 \mu \mathrm{L}$ of Reagent 1 with $75 \mu \mathrm{L}$ of each plasma sample and the absorbance value of each sample was measured at $530 \mathrm{~nm}$ after 30 minutes. $15 \mu \mathrm{L}$ of Reagent 2 was then added to the mixture, the absorbance was read at $530 \mathrm{~nm}$ again. Calibration of the assay was conducted with $\mathrm{H}_{2} \mathrm{O}_{2}$ and the results were expressed as $\mu \mathrm{M} \mathrm{H}_{2} \mathrm{O}_{2}$ equivalent per liter $\left(\mu \mathrm{mo} \mathrm{H}_{2} \mathrm{O}_{2}\right.$ equiv./L).

\section{Sister Chromatid Exchange (SCE) Method}

5-bromo-20-deoxyuridine (Sigma, St Louis, Missouri, USA; final concentration $20 \mathrm{mM}$ ) was added after culture initiation to provide better visualization of SCEs (Evans and O'Riordan, 1975). Exactly 70 hours and 30 minutes after the initiation of incubations, colcemid (Sigma) was added to the cultures to obtain a final concentration of $0.5 \mathrm{mg} / \mathrm{L}$. After hypotonic treatment $(0.075 \mathrm{M} \mathrm{KCl})$ and three repetitive cycles including fixation in methanol/acetic acid solution $(3: 1, \mathrm{v} / \mathrm{v})$, centrifugation, and resuspension, the cell suspension was dropped onto chilled and grease-free microscopic slides. Then slides were air-dried, aged, and stained differently for a variety of SCE ratio according to fluorescence plus Giemsa (FPG) preparation. For each treatment, 20 well-spread second division metaphases were scored and calculated as SCEs per cell.

\section{Micronucleus (MN) Assay}

The MN test was done by adding cytochalasin B (Sigma 1; 6 $\mathrm{mg} / \mathrm{mL}$ final concentration) after 44 hours of culture. After an incubation period of 72 hours, lymphocytes were fixed with ice-cold methanol: acetic acid (3:1). The cells were fixed directly on the slides using a cytospin and stained with Giemsa. The scoring criteria for micronuclei were defined by Fenech (1993). 2000 binucleated lymphocytes were screened per concentration (two cultures for each concentration) for the presence of one, two, or more micronuclei.

\section{Statistical Analysis}

Statistical analysis was performed using SPSS 18.0 (SPSS, Chicago, IL, USA). The experimental data were analyzed by one-way analysis of variance (ANOVA) and Duncan's test was performed to examine whether there were any differences between the application and control groups. The results are presented as means $\pm \mathrm{SD}$ of at least three independent experiments and $\mathrm{P}<0.05$ was accepted as significant. All assays were run in triplicate.

\section{Results and Discussion}

\section{Cell Viability}

The cytotoxic effects of different concentrations of $P$. pavonica extract were evaluated by MTT assay (Figure 1). The results showed that mitomycin $\mathrm{C}$, as a positive control, significantly decreased $(\mathrm{P}<0.05)$ cell viability with a fold decrease of 2.6 compared to untreated control. However, lower doses $(0.5,5,25,50,100,250$, and $500 \mu \mathrm{g} / \mathrm{mL})$ of $P$. pavonica did not cause $(\mathrm{P}>0.05)$ a change in cell viability while $1000 \mu \mathrm{g} / \mathrm{mL}$ concentration significantly inhibited $(\mathrm{P}<0.05)$ cell viability with a fold decrease of 2.6. 


\section{TAC and TOS Activity}

As shown in Figures 2 and 3, ascorbic acid and $\mathrm{H}_{2} \mathrm{O}_{2}$, used as a positive control, significantly increased $(\mathrm{P}<0.05)$ the TAC and TOS levels with a 2.46 and 3.03 -fold increase, respectively. However, only 50 (1.3-fold increase) and 100 (2-fold increase) $\mu \mathrm{g} / \mathrm{mL}$ concentrations of $P$. pavonica led to a statistically significant increase $(\mathrm{P}<0.05)$ in TAC levels as compared to untreated control cells. When oxidative status after exposure treatments was investigated, the concentration of $1000 \mu \mathrm{g} / \mathrm{mL}$ of $P$. pavonica caused an increase $(\mathrm{P}<0.05)$ with a fold change of 1.4 in TOS levels.

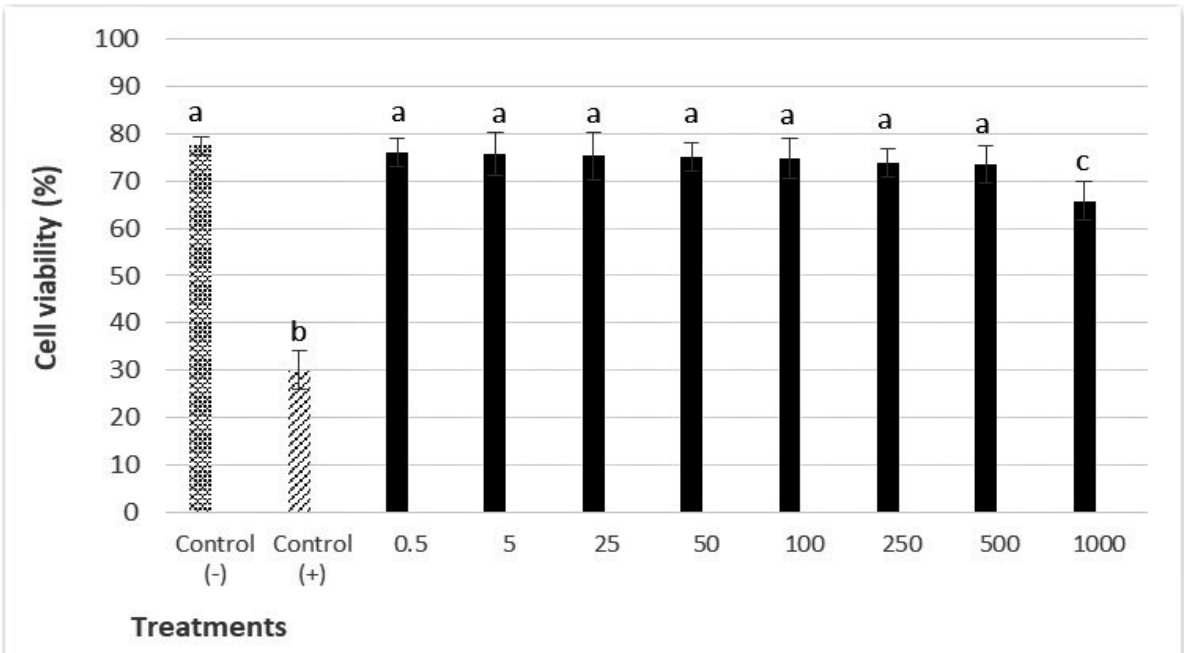

Figure 1. Effect of different concentrations of Padina pavonica water extract on human lymphocytes at $24 \mathrm{~h}$. Values represent means $\pm \mathrm{SD}$ of at least three experiments. Bars indicated by the different letters $(a, b, c)$ show statistically significant differences at the $\mathrm{P}<0.05$ level. Mitomycin $\mathrm{C}\left(10^{-7} \mathrm{M}\right)$ was used as a positive control.

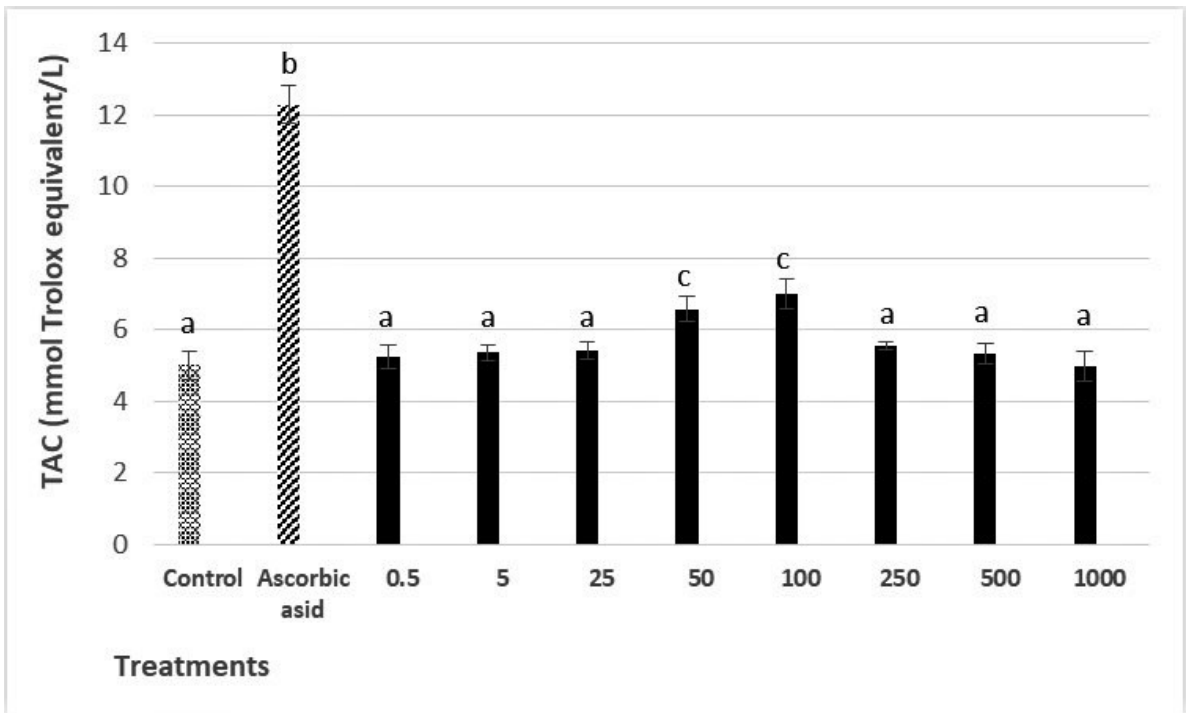

Figure 2. The TAC levels in cultured human lymphocytes exposed to various concentrations of Padina pavonica for $2 \mathrm{~h}$. Values represent means \pm SD of at least three experiments. Bars indicated by the different letters $(a, b, c)$ show $(a, b, c)$ statistically significant differences at the $\mathrm{P}<0.05$ level. Ascorbic acid $(10 \mathrm{mM})$ used a positive control. 


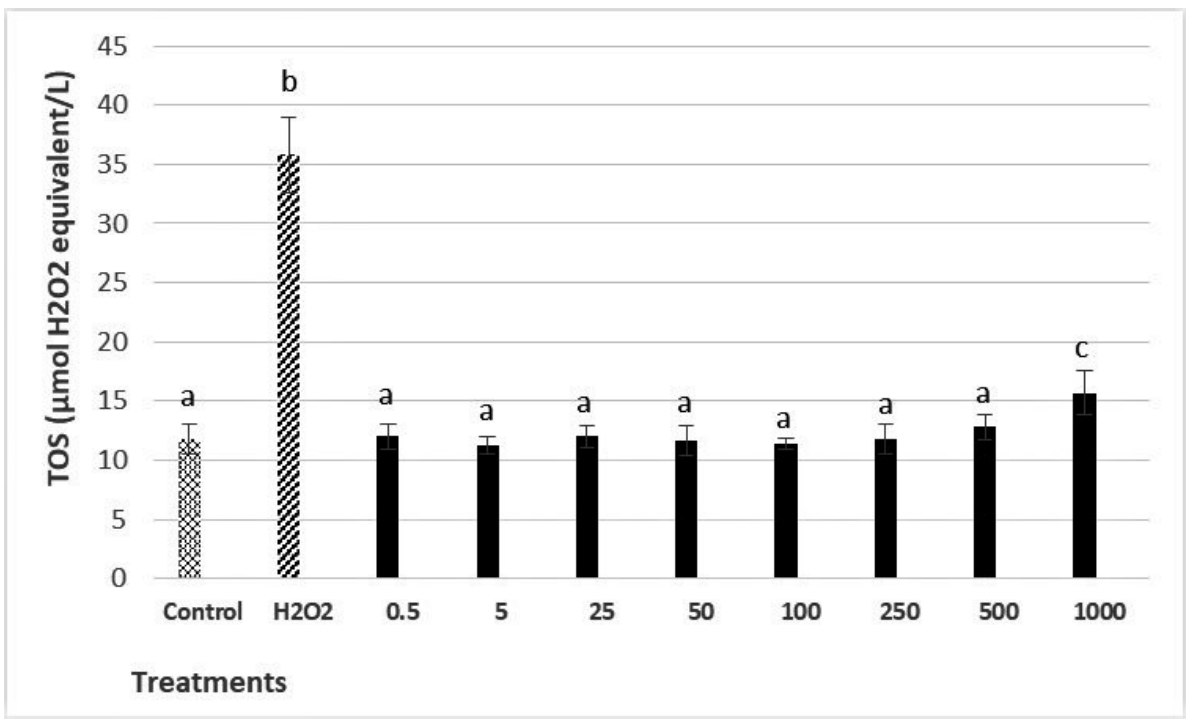

Figure 3. The TOS levels in cultured human lymphocytes exposed to various concentrations of Padina pavonica for $2 \mathrm{~h}$. Values represent means $\pm \mathrm{SD}$ of at least three experiments. Bars indicated by the different letters $(a, b, c)$ show statistically significant differences at the $\mathrm{P}<0.05$ level. Hydrogen peroxide $\left(\mathrm{H}_{2} \mathrm{O}_{2}\right)(25 \mathrm{mM})$ was used as a positive control.

\section{Genotoxicity Activities}

The MN and SCE frequencies on lymphocytes exposed to $P$. pavonica were depicted in Figure 4. P. pavonica did not induce a significant $(\mathrm{P}>0.05)$ changes in $\mathrm{MN}$ and $\mathrm{SCE}$, even at the highest concentrations. However, mitomycin $\mathrm{C}$, as a positive control, caused a significant increase $(\mathrm{P}<0.05)$ in $\mathrm{MN}$ and SCE ratios as compared to the untreated control.

The present study revealed for the first time cytotoxic effects of $P$. pavonica on human lymphocytes, in a dose-dependent manner. Briefly, an increase in sample dose caused a reduction in cell viability. Mashjoor et al., (2016) reported that Padina antillarum and Padina boergeseni showed cytotoxic effects in different cell lines (Vero, MCF-7, and HeLa), in a dose-dependent manner. Previous reports declared that a concentration of $50 \mu \mathrm{g} / \mathrm{mL}$ of Halopteris scoparia (brown algae) significantly inhibited viability in HEK 293 cells, in accordance with our findings (Güner et al., 2019). Another study showed that hexane, chloroform, and methanol extracts of Sargassum swartzii and Cystoseira myrica brown algae exerted cytotoxic effects in CaCo-2 and T47D while Colpomenia sinuosa did not cause any cytotoxicity on these cell lines (Khanavi et al., 2010). Cystoseira compressa extracts had no significant cytotoxic activity against Hep 3B cells in all treated concentrations (Güner et al., 2015). These different cytotoxic activities may be related to the extraction/solvent type used and the different sensitivity of the cells.

In a normal cellular process, there is a balance between antioxidant and oxidant status. When cellular damage is induced by different agents, this situation causes an increase in oxidative radical levels and consequently, many dramatic events occur for the cell. For this purpose, oxidative changes in lymphocytes after exposure to $P$. pavonica were determined by TAC and TOS tests. The major advantage of these assays is to measure all the antioxidant/oxidant capacity in the medium and not just the oxidant/antioxidant level of a compound in a culture sample (Kusano and Ferrari 2008). Lower concentrations (50 and $100 \mu \mathrm{g} / \mathrm{mL}$ ) of $P$. pavonica led to a statistically significant increase in TAC levels as compared to untreated control cells. In other words, the algae sample at the lower dose acted as an antioxidant agent. Similarly, many studies provided the antioxidant activity of algae species. Al-Enazi et al., (2018) reported that $P$. pavonica extracts had an excellent antioxidant activity with a value of IC50 $=5.59 \mu \mathrm{g} / \mathrm{mL}$, in a concentration-dependent manner. In another study comparing the biological effects of different algae samples, $P$. pavonica showed the highest antioxidant activity (Khaled et al., 2012). Previous studies have shown a highly significant correlation between antioxidant activity and polar contents such as polysaccharides, ketones, amines, phenols, aldehydes 
in plants (Roopashree and Naik, 2019). The antioxidant effects of $P$. pavonica may be explained by the presence of secondary metabolites in the water extract. On the other hand, $P$. pavonica (at $500 \mu \mathrm{g} / \mathrm{mL}$ and below concentrations) did not cause any change in TOS levels while $1000 \mu \mathrm{g} / \mathrm{ml}$ treatment significantly increased TOS levels in lymphocytes as compared to control. Thus, the cytotoxic effects of $P$. pavonica could be attributed, at least in part, to oxidative stress induced by high algae contents.

When oxidative stress occurs, the evaluation of damages in DNA is one of the most important outcomes. To this end, whether the oxidative stress triggered by $P$. pavonica causes genetic damage was evaluated by the SCE and MN methods. SCE is considered to be a very simple and sensitive cytogenetic assay for evaluating the genotoxic effects of potentially mutagenic and carcinogenic agents (Das 1988). The MN assay is also a very sensitive and rapid method that can detect both clastogenic and aneugenic effects of agents (Migliore et al. 1989). Our results showed that P. pavonica was non-genotoxic. In other words, the algae sample did not cause any significant increases in the levels of the SCE and MN in lymphocytes as compared to control values, even at the highest concentrations. A previous study conducted by bacterial Vitotox ${ }^{\circledR}$ test and micronucleus assay reported that Dictyopteris membranacea (brown algae) did not cause any genotoxic effects in human $\mathrm{C} 3 \mathrm{~A}$ cells, even at the highest concentrations (Akremi et al., 2016). Similarly, another study related to the genotoxic effects of algae species declared similar results that algae species did not cause any clastogenic and DNA disrupting effects in mice bone marrow erythrocytes at the highest dose of $2000 \mathrm{mg} / \mathrm{kg}$ body (Bello et al., 2019). Sulfated polysaccharides from brown algae are one of the potential compounds used in medical applications. Previous studies have reported that fucoidan obtained from different algae species have no genotoxic effect in vivo and in vitro assay (Kim et al., 2010; Song et al., 2012).

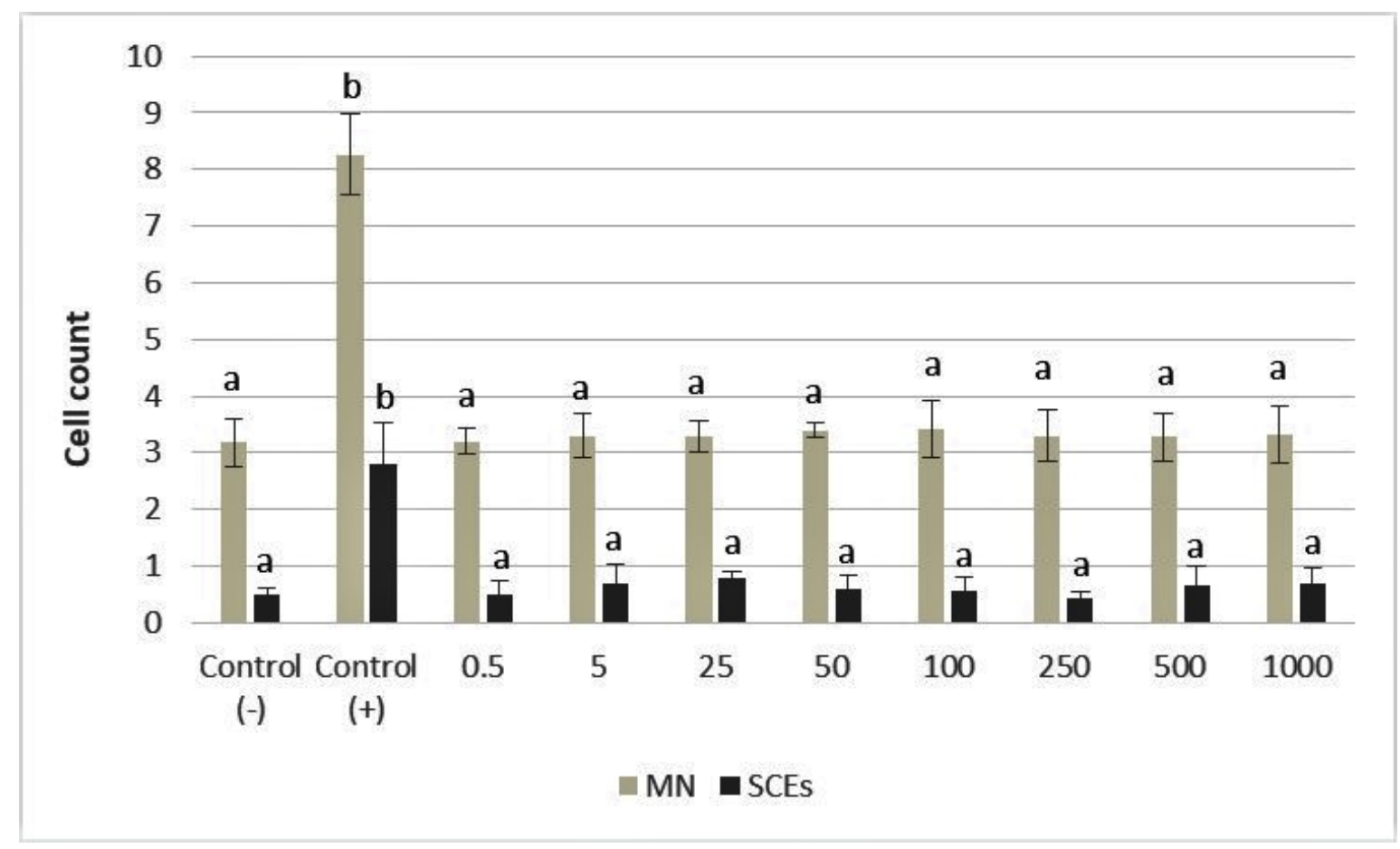

Figure 4. The frequencies of micronucleus (MN) and sister chromatid exchange (SCEs) values in human lymphocyte treated with various concentrations of Padina pavonica for $72 \mathrm{~h}$ (Positive control: Mitomycin $\mathrm{C}\left(10^{-7} \mathrm{M}\right)$. Values represent means $\pm \mathrm{SD}$ of at least three experiments. Bars indicated by the different letters $(\mathrm{a}, \mathrm{b}, \mathrm{c})$ show statistically significant differences at the $\mathrm{P}<0.05$ level. 


\section{Conclusions}

In conclusion, the present results clearly showed that $P$. pavonica had no genotoxic effects on lymphocytes. Furthermore, this algae sample exhibited antioxidant properties dependent on the applied concentration. In this context, $P$. pavonica has the potential of being utilized as both novel bioresources and safely consumed.

\section{Compliance with Ethical Standard}

Conflict of interests: The authors declare that for this article they have no actual, potential or perceived the conflict of interests.

Ethics committee approval: Author declare that this study does not include any experiments with human or animal subjects.

Funding disclosure: -

Acknowledgments: -

Disclosure: -

\section{References}

Akremi, N., Cappoen, D., Anthonissen, R., Bouraoui, A., Verschaeve, L. (2016). Evaluation of the genotoxicity and cytotoxicity of semipurified fractions from the Mediterranean brown algae, Dictyopteris membranacea. Pharmacognosy Magazine, 12(Suppl 4), S395.

https://doi.org/10.4103/0973-1296.188318

Al-Enazi, N.M., Awaad, A.S., Zain, M.E., Alqasoumi, S.I. (2018). Antimicrobial, antioxidant and anticancer activities of Laurencia catarinensis, Laurencia majuscula and Padina pavonica extracts. Saudi Pharmaceutical Journal, 26(1), 4452.

https://doi.org/10.1016/i.jsps.2017.11.001

Atmaca, H., İlhan, S., Batır, B., Pulat, Ç. Ç., Güner, A., Bektaş, H. (2020). Novel benzimidazole derivatives: Synthesis, in vitro cytotoxicity, apoptosis and cell cycle studies. Chemico-Biological Interactions, 109163.

https://doi.org/10.1016/j.cbi.2020.109163

Bello, A., Padmanabhan, S., Thangamalai, R., Lakshmanan, K., Nagarajan, K. (2019). Evaluation of genotoxic effects of methanolic extract of brown seaweed Stoechospermum marginatum. The Journal of Phytopharmacology, 8(5), 226-231.

https://doi.org/10.31254/phyto.2019.8504
Cherry, P., O'Hara, C., Magee, P.J., McSorley, E.M., Allsopp, P.J. (2019). Risks and benefits of consuming edible seaweeds. Nutrition Reviews, 77(5), 307-329.

https://doi.org/10.1093/nutrit/nuy066

Das, B.C. (1988). Factors that influence formation of sister chromatid exchanges in human blood lymphocytes. CRC Critical Reviews in Toxicology, 19(1), 43-86.

https://doi.org/10.3109/10408448809040817

Evans, H.J., O'Riordan, M.L. (1975). Human peripheral blood lymphocytes for the analysis of chromosome aberrations in mutagen tests. Mutation Research, 31, 135-148. https://doi.org/10.1016/0165-1161(75)90082-5

Field, C.B., Behrenfeld, M.J., Randerson, J.T., Falkowski, P. (1998). Primary production of the biosphere: integrating terrestrial and oceanic components. Science, 281, 237-240. https://doi.org/10.1126/science.281.5374.237

Fenech, M. (1993). The cytokinesis-block micronucleus technique: a detailed description of the method and its application to genotoxicity studies in human populations. Mutation Research, 285, 35-44.

https://doi.org/10.1016/0027-5107(93)90049-L

Güner, A., Türkez, H., Aslan, A. (2012). The In Vitro Effects of Dermotocarpon Intestiniforme (A Lichen) Extracts Against Cadmium Induced Genetic and Oxidative Damage. Ekoloji. 21(84), 38-46.

https://doi.org/10.5053/ekoloji.2012.845

Güner, A., Köksal, Ç., Erel, Ş.B., Kayalar, H., Nalbantsoy, A., Sukatar, A., Karabay Yavaşoğlu, N.Ü. (2015). Antimicrobial and antioxidant activities with acute toxicity, cytotoxicity and mutagenicity of Cystoseira compressa (Esper) Gerloff \& Nizamuddin from the coast of Urla (Izmir, Turkey). Cytotechnology, 67, 135-143.

https://doi.org/10.1007/s10616-013-9668-x

Güner, A., Karabay Yavasoğlu, N.U. (2018). Evaluation of antioxidant, antimicrobial and antimutagenic activity with irritation effects of Ceramium rubrum (Red Algae) extract. International Journal of Secondary Metabolite, 5, 279-287.

https://doi.org/10.21448/ijsm.432654

Güner, A., Nalbantsoy, A., Sukatar, A., Karabay Yavaşoğlu, N.Ü. (2019). Apoptosis-inducing activities of Halopteris scoparia L. Sauvageau (brown algae) on cancer cells and its biosafety and antioxidant properties. Cytotechnology, 71(3), 687-704. 


\section{https://doi.org/10.1007/s10616-019-00314-5}

Güner, Ö., Güner, A., Yavaşoğlu, A., Karabay Yavaşoğlu, N.Ü., Kavlak, O. (2020). Ameliorative effect of edible Halopteris scoparia against cadmium-induced reproductive toxicity in male mice: A biochemical and histopathologic study. Andrologia, 52(6), e13591.

https://doi.org/10.1111/and.13591

Khaled, N., Hiba, M., Asma, C. (2012). Antioxidant and Antifungal Activities of Padina pavonica and Sargassum vulgare from the Lebanese Mediterranean Coast. Advances in Environmental Biology, 6, 42-48.

Khanavi, M., Nabavi, M., Sadati, N., Shams Ardekani, M., Sohrabipour, J., Nabavi, S.M.B., Ghaeli P., Ostad, S.N. (2010). Cytotoxic activity of some marine brown algae against cancer cell lines. Biological Research, 43(1), 31-37. https://doi.org/10.4067/S0716-97602010000100005

Kim, K.J., Lee, O.H., Lee, B.Y. (2010). Genotoxicity studies on fucoidan from Sporophyll of Undaria pinnatifida. Food and Chemical Toxicology, 48(4), 1101-1104.

https://doi.org/10.1016/j.fct.2010.01.032

Kusano, C., Ferrari, B. (2008). Total antioxidant capacity: a biomarker in biomedical and nutritional studies. Journal of Molecular Cell Biology, 7, 1-15.

Mashjoor, S., Yousefzadi, M., Esmaeili, M.A., Rafiee, R. (2016). Cytotoxicity and antimicrobial activity of marine macroalgae (Dictyotaceae and Ulvaceae) from the Persian Gulf. Cytotechnology, 68(5), 1717-1726.

https://doi.org/10.1007/s10616-015-9921-6
McHugh, D.J. (2003). A guide to the seaweed industry. FAO Fish Tech Pap 441, Rome, Italy, p 105, ISBN 92-5-104958-0

Migliore, L., Nieri, M., Amodio, S., Loprieno, N. (1989). The human lymphocyte micronucleus assay: a comparison between whole-blood and separated-lymphocyte cultures. Mutation Research Letters, 227(3), 167-172. https://doi.org/10.1016/0165-7992(89)90041-9

Mohamed, S., Hashim, S.N., Rahman, H.A. (2012). Seaweeds: a sustainable functional food for complementary and alternative therapy. Trends in Food Science \& Technology, 23, 83-96.

https://doi.org/10.1016/j.tifs.2011.09.001

Pereira, L. (2016). Edible seaweeds of the world. CRC Press, Boca Raton, p 52. ISBN: 13:978-1-4987-3050-1

https://doi.org/10.1201/b19970

Roopashree, K.M., Naik, D. (2019). Advanced method of secondary metabolite extraction and quality analysis. Journal of Pharmacognosy and Phytochemistry, 8(3), 1829-1842.

Song, M.Y., Ku, S.K., Han, J.S. (2012). Genotoxicity testing of low molecular weight fucoidan from brown seaweeds. Food and Chemical Toxicology, 50(3-4), 790-796.

https://doi.org/10.1016/j.fct.2011.11.010

Stanojkovic, T.P., Savikin, K., Zdunic, G., Kljajic, Z., Grozdanic, N., Antic, J. (2013). In Vitro Antitumoral Activities of Padina pavonica on Human Cervix and Breast Cancer Cell Lines. Journal of Medicinal Plants Research, 7, 419424. 